\title{
Comparing mineral and fossil surplus costs of renewable and non-renewable electricity production
}

\author{
Marisa D. M. Vieira ${ }^{1,2}$ - Mark A. J. Huijbregts ${ }^{1}$
}

Received: 9 October 2016 / Accepted: 17 May 2017 / Published online: 1 June 2017

(C) The Author(s) 2017. This article is an open access publication

\begin{abstract}
Purpose Life cycle assessment aims to assess trade-offs between different impacts, including mineral and fossil resource use. The goals of this study were (1) to derive surplus cost potentials (SCPs) for a large number of fossil and mineral resources and (2) to derive surplus costs per megawatt hour of electricity produced for a range of both renewable and nonrenewable technologies.

Methods The SCP of a resource refers to the total cost increase over the full amount of resource expected to be extracted in the future, expressed as US dollar (USD) per unit of resource extracted. For the fossil resources oil, natural gas and hard coal, cost-cumulative production relationships were derived that were subsequently used as input to calculate SCPs for these three fossil resources. For mineral resources, SCPs were readily available for 12 resources and platinumgroup metals as a separate group. SCPs for an additional number of 57 mineral resources and 4 mineral resource groups were derived on the basis of a statistical relationship between SCP and average price in year 2013. The SCPs of fossil and
\end{abstract}

Responsible editor: Gian Luca Baldo

Electronic supplementary material The online version of this article (doi:10.1007/s11367-017-1335-6) contains supplementary material, which is available to authorized users.

Marisa D. M. Vieira

vieira@pre-sustainability.com

1 Faculty of Science, Department of Environmental Science, Radboud University Nijmegen, P.O. Box 9010, 6500

GL Nijmegen, Netherlands

2 PRé Consultants bv, Stationsplein 121, 3818

LE Amersfoort, Netherlands mineral resources were subsequently used to derive the surplus costs per megawatt hour of 10 electricity production technologies.

Results and discussion The surplus costs of electricity production ranged from 0.3 to $148 \mathrm{USD}_{2013} / \mathrm{MWh}$. The three fossil-based energy production technologies, based on coal, gas and oil, resulted in the highest overall surplus costs (23 to $148 \mathrm{USD}_{2013} / \mathrm{MWh}$ ), while nuclear, geothermal, photovoltaic, wind and hydropower technologies have the lowest surplus costs $\left(0.3-6 \mathrm{USD}_{2013} / \mathrm{MWh}\right)$. We found that the contribution of fossil resource use to the surplus costs was higher compared to mineral resource use, including the renewable energy technologies.

Conclusions Surplus costs of fossil and mineral resources can be used to compare renewable and non-renewable electricity production technologies. This case study shows that fossil fuel use drives the surplus costs of all energy technologies.

Keywords Electricity production $\cdot$ Fossil fuels $\cdot$ Life cycle assessment (LCA) · Metals · Mineral resources · Scarcity · Surplus cost potential (SCP)

\section{Introduction}

There is an urgent need to limit global warming to $2{ }^{\circ} \mathrm{C}$ or lower relative to pre-industrial levels. To reach this target, greenhouse gas (GHG) emissions need to be substantially reduced which particularly come from the burning of fossil fuels (IPCC 2014). To add to this challenge, large emerging economies, such as Brazil, China and India, are experiencing great economic and population growth (Alam et al. 2016; Haseeb et al. 2016; Zaman et al. 2016). This leads to a significant increase in consumption of resources, for instance in housing, vehicles and electronics. In the past years, an 
accelerated shift toward renewable (low-carbon) energy technologies can be observed (International Energy Agency 2015). The large-scale implementation of renewable energy technologies, however, comes with increased use of mineral resources, such as copper for photovoltaic systems and iron for wind power plants (Hertwich et al. 2014; Kleijn et al. 2011; Pehlken et al. 2017).

When comparing different electricity production technologies, trade-off evaluation with life cycle assessment is crucial (Prado-Lopez et al. 2016). To evaluate the trade-offs in using fossil vs. mineral resources to produce energy, surplus cost can be used as an indicator. The surplus cost potential of a resource is a suggested measure of the short-term economic scarcity of that resource assuming that its production costs will increase with continued production. Steen (1999) was the first to propose surplus cost as an indicator to assess the life cycle impacts of products, services and technologies. Despite this development from the 90s and others that followed, currently there is still extensive debate about natural resources in life cycle impact assessment (LCIA) (Dewulf et al. 2015; Drielsma et al. 2016; Lieberei and Gheewala 2017; Sonderegger et al. 2017; Steen and Palander 2016). The European Commission-Joint Research Centre-Institute for Environment and Sustainability (2011) indicated surplus costs as a promising approach to quantify abiotic resource scarcity but has, nevertheless, considered it not mature for recommendation in the evaluation of product life cycle impacts. Drielsma et al. (2016) also point to the potential of using economic scarcity as indicator for short-term availability. The surplus cost potential indicator can be seen as one example of how economic scarcity can be used in LCIA-based resource scarcity assessments. Recently, Vieira et al. (2016) derived surplus cost potentials (SCP) for metals, quantifying the average cost increase expected from future resource extractions. They described the relation between costs and extraction with cost-cumulative tonnage relationships and considered two different reserve estimates, i.e. (economic demonstrated) reserves and ultimate recoverable resource, in their SCP calculations. Ponsioen et al. (2014) derived SCPs for fossil fuels with cost-cumulative tonnage curves as well but focussed on marginal cost changes in the current situation and considered economic discounting in their calculations. Although substantial progress has been made in the further development of the SCP method, for practical application, the number of mineral resources needs to be expanded and the assessment of fossil fuels and mineral resources needs to be aligned (Klinglmair et al. 2014).

The goal of the study was to derive average surplus cost potentials for a large number of mineral and fossil resources. The SCPs were subsequently applied to derive surplus costs for non-renewable (hard coal, natural gas, oil, nuclear) and renewable (wind, solar, hydro, geothermal) electricity production in 56 countries.

\section{Methods and data}

\subsection{Fossil resources}

The SCP of fossil resource $x$ was calculated by

$\mathrm{SCP}_{x}($ fossil $)=\frac{\int_{\mathrm{CFE}_{x}}^{\mathrm{MFE}_{x}}\left(\Delta C_{x}\right) d \mathrm{FE}_{x}}{\mathrm{R}_{x}}$

where $C_{x}$ is the production cost of fossil resource $x$ (in USD $/ \mathrm{kg}$ or USD $/ \mathrm{Nm}^{3} x$ ) determined via a cost-cumulative production relationship (see Eq. (2)), $\mathrm{FE}_{x}$ is the future extraction (in $\mathrm{kg}$ or $\left.\mathrm{Nm}^{3}\right), R_{x}$ is the total future production (in $\mathrm{kg}$ or $\mathrm{Nm}^{3}$ ), $\mathrm{MFE}_{x}$ is the maximum amount available for extraction (in $\mathrm{kg}$ or $\mathrm{Nm}^{3}$ ) and $\mathrm{CFE}_{x}$ is the current cumulative tonnage (in $\mathrm{kg}_{\text {or }} \mathrm{Nm}^{3}$ ) of fossil resource $x$ extracted. There is a very important assumption of this model, namely that all reserves up to MFE will be extracted. The cumulative fossil resource extracted (CFE), the maximum amount available (MFE) and the actual reserve (MFE - CFE) for crude oil, hard coal and natural gas were taken from the International Energy Agency (2013) (see the Electronic Supplementary Material and Fig. 1).

The cost of fossil resource $x$ was based on the cumulative tonnage extracted of that fossil resource. The relationship between the two variables was derived by fitting a log-linear curve through the cost and cumulative production:

$C_{x}=\frac{1}{a_{x}+b_{x} \cdot \ln \left(\mathrm{CFE}_{x}\right)}$

where $a_{x}$ and $b_{x}$ are, respectively, the intercept and slope of the $\log$-linear distribution of the cost-cumulative production relationship for fossil resource $x$.

The data used to derive the cost-cumulative production relationships for crude oil, natural gas and hard coal was retrieved from the International Energy Agency (2013). The cost data reported by the International Energy Agency (2013) was in 1998 US dollars. The CPI Inflation Calculator (Bureau of Labor Statistics 2014) was used to convert the CFs into US dollars for $2013\left(\mathrm{USD}_{2013}\right)$. For crude oil and natural gas, the data of the IEA includes the costs and amounts of fossil resources extracted up to now and expected for the future per production technique, e.g. conventional oil or oil in ultra-deep water. For hard coal, a production-cost curve is provided with free-on-rail (FOR) production costs up to the 2011 estimate of 728 gigatonnes (Gt) of global hard coal reserves (International Energy Agency 2013). The FOR production cost includes the cost of mining and delivering the coal from the mine plus surface handling, coal preparation or beneficiation, storage and loading costs. The International Energy Agency (2013) estimates require assumptions related to the different factors influencing production costs, such as differences in the specific resource category to be exploited, the location of current and future reservoirs and the evolution 
Fig. 1 Visualization of the derivation of the surplus cost potential following an average approach and a log-linear costcumulative production curve from the current cumulative fossil extracted $(C F E)$ up to the global maximum fossil available for extraction (MFE)

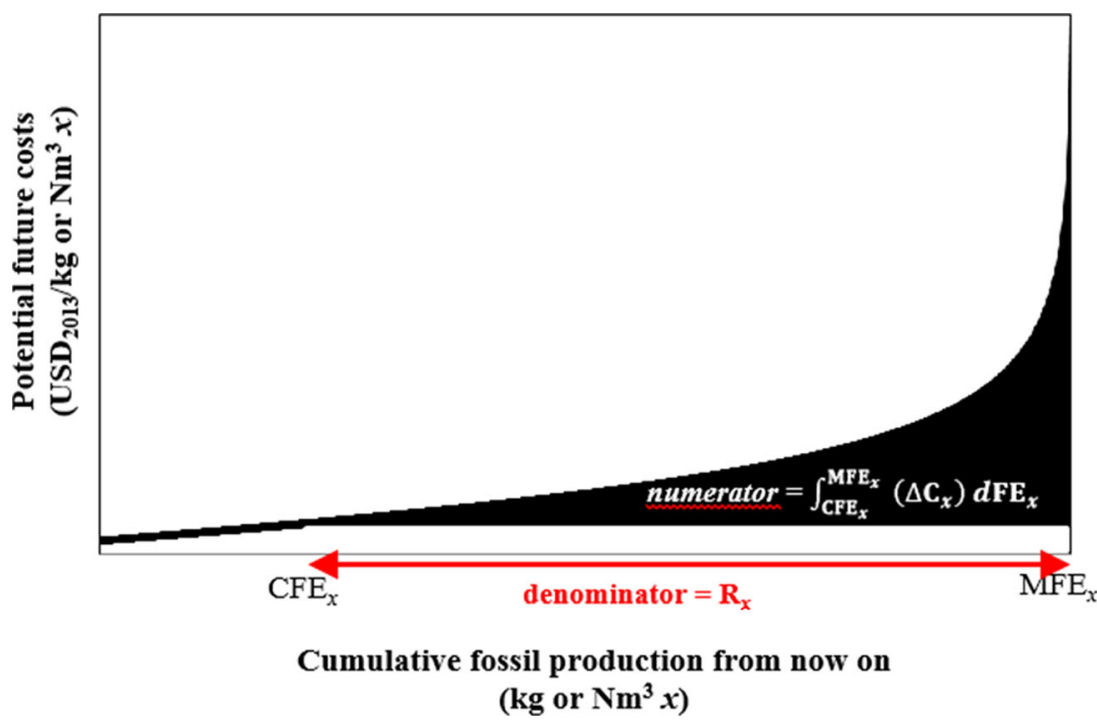

are no SCPs available because cost and extraction data per mine are lacking. Here, we extended the number of metals and mineral resources covered by deriving a log-linear relationship between surplus cost potentials and prices for metals and mineral resources:

$\mathrm{SCP}_{x}($ mineral $)=10^{a} \times$ price $^{b}$

where $a$ and $b$ are, respectively, the intercept and slope of the log-linear regression. In commoditized markets, as is the case for mineral and metal resources, price tends to converge toward cost (Crowson 2011; Dixon 2009; Tilton and Lagos 2007).

For the regression analysis, the mineral SCPs of Vieira et al. (2016) were used, while price data for 2013 was retrieved from Kelly and Matos (2013) except for the platinum-group metals and uranium. For palladium, platinum and rhodium, average price data for 2013 was retrieved from Kitco Metals Inc. (2015). The ESA spot $\mathrm{U}_{3} \mathrm{O}_{8}$ data (a weighted average of triuranium octoxide prices paid by EU utilities for uranium delivered under spot contracts during the reference year) published by the Euratom Supply Agency (2015) was used to calculate the price for uranium. The SCP and price values of the 12 resources and platinum-group metals as a group that were used as input to construct the regression model are reported in Table 1 and in the Electronic Supplementary Material, respectively.

The regression was applied to 57 additional mineral resources and for the groups garnets, gemstones, rare earths and zirconium mineral concentrates to derive SCP values from price data. The price data can also be found in the Electronic Supplementary Material.

\subsection{Electricity production technologies}

Data for 10 electricity technologies has been retrieved from ecoinvent v3.2, system model Recycled content (Ecoinvent 
Table 1 Surplus cost potential (SCP) of fossil and mineral resources, the latter determined for reserves

\begin{tabular}{|c|c|c|c|c|}
\hline Name & Unit & Element & $\begin{array}{l}\text { Surplus cost potential } \\
\text { (SCP) } \text { USD }_{2013} / \text { unit }\end{array}$ & Source \\
\hline Crude oil & $\mathrm{kg}$ & & $4.57 \times 10^{-1}$ & Empirically derived \\
\hline Natural gas & $\mathrm{Nm}^{3}$ & & $3.01 \times 10^{-1}$ & Empirically derived \\
\hline Hard coal & $\mathrm{kg}$ & & $3.41 \times 10^{-2}$ & Empirically derived \\
\hline Crude oil & GJhhv & & $9.97 \times 10^{0}$ & Empirically derived \\
\hline Natural gas & GJhhv & & $7.87 \times 10^{0}$ & Empirically derived \\
\hline Hard coal & GJhhv & & $1.79 \times 10^{0}$ & Empirically derived \\
\hline Aluminium & $\mathrm{kg}$ & $\mathrm{Al}$ & $4.03 \times 10^{-1}$ & Derived from price \\
\hline Antimony & $\mathrm{kg}$ & $\mathrm{Sb}$ & $1.89 \times 10^{0}$ & Derived from price \\
\hline Arsenic & $\mathrm{kg}$ & As & $1.57 \times 10^{-1}$ & Derived from price \\
\hline Ball clay & $\mathrm{kg}$ & & $9.27 \times 10^{-3}$ & Derived from price \\
\hline Barite & $\mathrm{kg}$ & & $2.88 \times 10^{-2}$ & Derived from price \\
\hline Bauxite & $\mathrm{kg}$ & & $6.06 \times 10^{-3}$ & Derived from price \\
\hline Bentonite clay & $\mathrm{kg}$ & & $1.39 \times 10^{-2}$ & Derived from price \\
\hline Beryllium & $\mathrm{kg}$ & $\mathrm{Be}$ & $7.57 \times 10^{1}$ & Derived from price \\
\hline Bismuth & $\mathrm{kg}$ & $\mathrm{Bi}$ & $3.48 \times 10^{0}$ & Derived from price \\
\hline Boron & $\mathrm{kg}$ & B & $1.39 \times 10^{-1}$ & Derived from price \\
\hline Cadmium & $\mathrm{kg}$ & $\mathrm{Cd}$ & $3.73 \times 10^{-1}$ & Derived from price \\
\hline Cesium & $\mathrm{kg}$ & $\mathrm{Ce}$ & $1.00 \times 10^{4}$ & Derived from price \\
\hline Chromium & $\mathrm{kg}$ & $\mathrm{Cr}$ & $4.56 \times 10^{-1}$ & Derived from price \\
\hline Chrysotile & $\mathrm{kg}$ & & $3.56 \times 10^{-1}$ & Derived from price \\
\hline Clay, unspecified & $\mathrm{kg}$ & & $1.35 \times 10^{-2}$ & Derived from price \\
\hline Cobalt & $\mathrm{kg}$ & Co & $5.00 \times 10^{0}$ & Derived from price \\
\hline Copper & $\mathrm{kg}$ & $\mathrm{Cu}$ & $5.21 \times 10^{-1}$ & Vieira et al. (2016) \\
\hline Diamond (industrial) & $\mathrm{kg}$ & $\mathrm{C}$ & $8.99 \times 10^{1}$ & Derived from price \\
\hline Diatomite & $\mathrm{kg}$ & & $6.02 \times 10^{-2}$ & Derived from price \\
\hline Feldspar & $\mathrm{kg}$ & & $1.97 \times 10^{-2}$ & Derived from price \\
\hline Fire clay & $\mathrm{kg}$ & & $5.01 \times 10^{-3}$ & Derived from price \\
\hline Fuller's earth & $\mathrm{kg}$ & & $1.91 \times 10^{-2}$ & Derived from price \\
\hline Gallium & $\mathrm{kg}$ & $\mathrm{Ga}$ & $8.26 \times 10^{1}$ & Derived from price \\
\hline Germanium & $\mathrm{kg}$ & $\mathrm{Ge}$ & $3.00 \times 10^{2}$ & Derived from price \\
\hline Gold & $\mathrm{kg}$ & $\mathrm{Au}$ & $6.54 \times 10^{3}$ & Derived from price \\
\hline Graphite & $\mathrm{kg}$ & $\mathrm{C}$ & $2.27 \times 10^{-1}$ & Derived from price \\
\hline Gypsum & $\mathrm{kg}$ & & $3.80 \times 10^{-3}$ & Derived from price \\
\hline Hafnium & $\mathrm{kg}$ & $\mathrm{Hf}$ & $9.49 \times 10^{1}$ & Derived from price \\
\hline Ilmenite & $\mathrm{kg}$ & & $4.82 \times 10^{-2}$ & Derived from price \\
\hline Indium & $\mathrm{kg}$ & In & $1.01 \times 10^{2}$ & Derived from price \\
\hline Iodine & $\mathrm{kg}$ & I & $7.53 \times 10^{0}$ & Derived from price \\
\hline Iron & $\mathrm{kg}$ & $\mathrm{Fe}$ & $1.15 \times 10^{-2}$ & Vieira et al. (2016) \\
\hline Iron ore & $\mathrm{kg}$ & & $2.22 \times 10^{-2}$ & Derived from price \\
\hline Kaolin & $\mathrm{kg}$ & & $3.08 \times 10^{-2}$ & Derived from price \\
\hline Kyanite & $\mathrm{kg}$ & & $6.16 \times 10^{-2}$ & Derived from price \\
\hline Lead & $\mathrm{kg}$ & $\mathrm{Pb}$ & $1.44 \times 10^{-1}$ & Vieira et al. (2016) \\
\hline Lime & $\mathrm{kg}$ & & $2.55 \times 10^{-2}$ & Derived from price \\
\hline Lithium & $\mathrm{kg}$ & $\mathrm{Li}$ & $8.32 \times 10^{-1}$ & Derived from price \\
\hline Magnesium & $\mathrm{kg}$ & $\mathrm{Mg}$ & $8.96 \times 10^{-1}$ & Derived from price \\
\hline Manganese & $\mathrm{kg}$ & $\mathrm{Mn}$ & $1.39 \times 10^{0}$ & Vieira et al. (2016) \\
\hline Mercury & $\mathrm{kg}$ & $\mathrm{Hg}$ & $9.44 \times 10^{0}$ & Derived from price \\
\hline Molybdenum & $\mathrm{kg}$ & Mo & $2.15 \times 10^{0}$ & Vieira et al. (2016) \\
\hline
\end{tabular}


Table 1 (continued)

\begin{tabular}{|c|c|c|c|c|}
\hline Name & Unit & Element & $\begin{array}{l}\text { Surplus cost potential } \\
\text { (SCP) } \text { USD }_{2013} / \text { unit }\end{array}$ & Source \\
\hline Nickel & $\mathrm{kg}$ & $\mathrm{Ni}$ & $2.54 \times 10^{0}$ & Vieira et al. (2016) \\
\hline Palladium & $\mathrm{kg}$ & $\mathrm{Pd}$ & $1.92 \times 10^{3}$ & Vieira et al. (2016) \\
\hline Perlite & $\mathrm{kg}$ & & $1.19 \times 10^{-2}$ & Derived from price \\
\hline Phosphorus & $\mathrm{kg}$ & $\mathrm{P}$ & $1.73 \times 10^{-1}$ & Derived from price \\
\hline Platinum & $\mathrm{kg}$ & $\mathrm{Pt}$ & $6.30 \times 10^{3}$ & Vieira et al. (2016) \\
\hline Potash & $\mathrm{kg}$ & & $1.25 \times 10^{-1}$ & Derived from price \\
\hline Pumice and pumicite & $\mathrm{kg}$ & & $7.58 \times 10^{-3}$ & Derived from price \\
\hline Rhenium & $\mathrm{kg}$ & $\mathrm{Re}$ & $4.92 \times 10^{2}$ & Derived from price \\
\hline Rhodium & $\mathrm{kg}$ & $\mathrm{Rh}$ & $1.35 \times 10^{4}$ & Vieira et al. (2016) \\
\hline Rutile & $\mathrm{kg}$ & & $2.12 \times 10^{-1}$ & Derived from price \\
\hline Selenium & $\mathrm{kg}$ & $\mathrm{Se}$ & $1.39 \times 10^{1}$ & Derived from price \\
\hline Silicon & $\mathrm{kg}$ & $\mathrm{Si}$ & $4.95 \times 10^{-1}$ & Derived from price \\
\hline Silver & $\mathrm{kg}$ & $\mathrm{Ag}$ & $7.31 \times 10^{1}$ & Vieira et al. (2016) \\
\hline Strontium & $\mathrm{kg}$ & $\mathrm{Sr}$ & $1.06 \times 10^{-1}$ & Derived from price \\
\hline Talc & $\mathrm{kg}$ & & $4.70 \times 10^{-2}$ & Derived from price \\
\hline Tantalum & $\mathrm{kg}$ & $\mathrm{Ta}$ & $5.29 \times 10^{1}$ & Derived from price \\
\hline Tellurium & $\mathrm{kg}$ & $\mathrm{Te}$ & $1.93 \times 10^{1}$ & Derived from price \\
\hline Thallium & $\mathrm{kg}$ & $\mathrm{Tl}$ & $1.09 \times 10^{3}$ & Derived from price \\
\hline Tin & $\mathrm{kg}$ & Sn & $4.13 \times 10^{0}$ & Derived from price \\
\hline Titanium & $\mathrm{kg}$ & $\mathrm{Ti}$ & $9.93 \times 10^{-1}$ & Derived from price \\
\hline Titanium dioxide & $\mathrm{kg}$ & & $5.92 \times 10^{-1}$ & Derived from price \\
\hline Tripoli & $\mathrm{kg}$ & & $4.34 \times 10^{-2}$ & Derived from price \\
\hline Tungsten & $\mathrm{kg}$ & W & $8.23 \times 10^{0}$ & Derived from price \\
\hline Uranium & $\mathrm{kg}$ & $\mathrm{U}$ & $1.21 \times 10^{1}$ & Vieira et al. (2016) \\
\hline Vanadium & $\mathrm{kg}$ & $\mathrm{V}$ & $4.29 \times 10^{0}$ & Derived from price \\
\hline Wollastonite & $\mathrm{kg}$ & & $4.46 \times 10^{-2}$ & Derived from price \\
\hline Zinc & $\mathrm{kg}$ & $\mathrm{Zn}$ & $9.04 \times 10^{0}$ & Vieira et al. (2016) \\
\hline Garnets & $\mathrm{kg}$ & & $5.88 \times 10^{-2}$ & Derived from price \\
\hline Gemstones & $\mathrm{kg}$ & & $6.86 \times 10^{3}$ & Derived from price \\
\hline Platinum-group metals (PGM) & $\mathrm{kg}$ & & $5.35 \times 10^{3}$ & Vieira et al. (2016) \\
\hline Rare earth metals & $\mathrm{kg}$ & & $3.46 \times 10^{0}$ & Derived from price \\
\hline Zirconium mineral concentrates & $\mathrm{kg}$ & & $2.08 \times 10^{-1}$ & Derived from price \\
\hline
\end{tabular}

The items presented in italic are the metal/mineral groups, the others are individual metals or minerals

Centre 2015), as implemented in SimaPro v8.2 (PRé Consultants bv 2015). Because there was no data to derive specific SCP values for peat and lignite, no SCP value for these resources to calculate the surplus costs of the various electricity technologies was included.

Ecoinvent provides life cycle inventory data per energy technology for a total of 56 countries. When various datasets for a specific technology within a country were available, the average surplus costs were calculated. For Canada, China and the USA, datasets per electricity production technology for specific geographical regions within each country are provided. All regions were considered equally important for the country average calculations. As a final step, the average and variation of the surplus costs of a technology between the countries were calculated. More information on the datasets analysed in this study can be found in the Electronic Supplementary Material.

\section{Results}

\subsection{Characterization factors}

The regressions between cumulative extraction of a fossil resource and the increase in production costs per unit of fossil resource extracted resulted in explained variances of $78 \%$ (for hard coal), 91\% (natural gas) and 94\% (for crude oil). The 
Fig. 2 Log-linear relationships between the average price in 2013 $\left(\mathrm{USD}_{2013} / \mathrm{kg} x\right)$ and surplus cost potential $\left(\mathrm{USD}_{2013} / \mathrm{kg} x\right)$ derived for reserves $(R)$. The 12 metals and platinum-group metals as a group for which Vieira et al. (2016) derived SCP values were used. Note: both axes are presented in a logarithmic scale

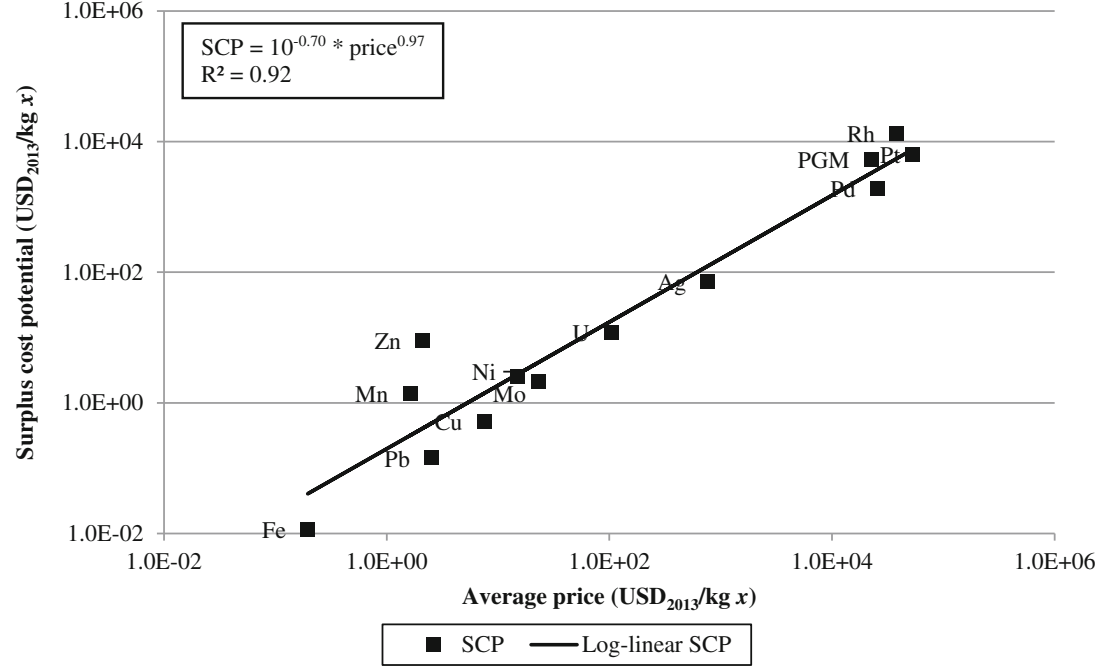

regression statistics for each fossil resource are reported in the Electronic Supplementary Material.

Table 1 shows the SCPs for the three fossil resources. The SCP value of crude oil is approximately 5.6 and 1.3 times larger than the SCP values of hard coal and natural gas, respectively.

As shown in Fig. 2, the surplus cost potential has a strong relationship with the price of a metal or mineral resource (explained variance of the regression is $92 \%$ ). The intercepts of the log-linear relationship between price and SCPs is -0.70 . This means that the SCP is typically a factor of $5\left(10^{0.70)}\right)$ smaller than the price of a metal or mineral resource. Table 1 provides a list of SCP values for all resources, with a distinction between those empirically derived here (fossil resources), the mineral resources empirically derived by Vieira et al. (2016) and the mineral resources derived on basis of the price.

\subsection{Surplus costs of electricity generation}

In Fig. 3, the surplus cost per megawatt hour of electricity produced is shown for every electricity production technology considered. Per electricity technology, the average over all countries is reported as well as the minimum and maximum surplus cost. Detailed results can be found in the Electronic Supplementary Material.

Hydroelectricity from run-of-river and from reservoir has the lowest surplus costs ( 0.3 to $\left.0.4 \mathrm{USD}_{2013} / \mathrm{MWh}\right)$. With around 2 to 3 orders of magnitude difference, the three fossil-based energy production technologies result in the highest overall surplus costs (23 to $148 \mathrm{USD}_{2013} / \mathrm{MWh}$ ). Nuclear, geothermal, photovoltaic and wind electricity production technologies result in intermediate results, namely between 1 and $8 \mathrm{USD}_{2013} / \mathrm{MWh}$. Note in this respect that the SCP for uranium obtained in our study is 0.02 $0.06 \mathrm{USD}_{2013} / \mathrm{GJ}$, converting from kilogram to gigajoules by its heat value of $500 \mathrm{GJ} / \mathrm{kg}$ (World Nuclear Association 2014). This implies that the surplus cost potential of uranium as energy resource is $1.5-2.7$ orders of magnitude lower than that of fossil resources.

From Fig. 3, it can also be seen that electricity production from wind shows the highest variability in SCP values, with approximately 2 orders of magnitude
Fig. 3 Surplus cost of different sources of electricity $\left(\mathrm{USD}_{2013} /\right.$ $\mathrm{MWh}$ ), calculated as the average of all country scores for that technology. The bars in this figure reflect the variability across countries considered showing the minimum and maximum country values

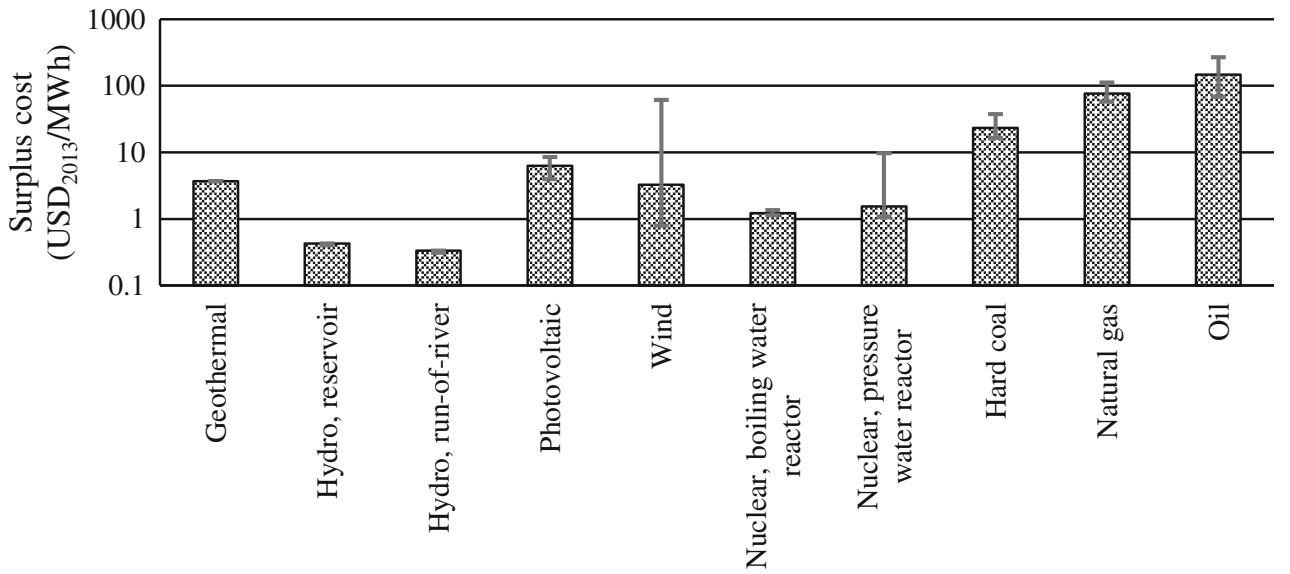


Fig. 4 Relative contribution of fossil and mineral resources to the surplus costs of various sources of electricity production. Mineral resources that contribute with at least $5 \%$ of the total SCP score per technology are individually shown and the rest is grouped in the series 'Remaining'. The contribution for all three fossil resources is always displayed

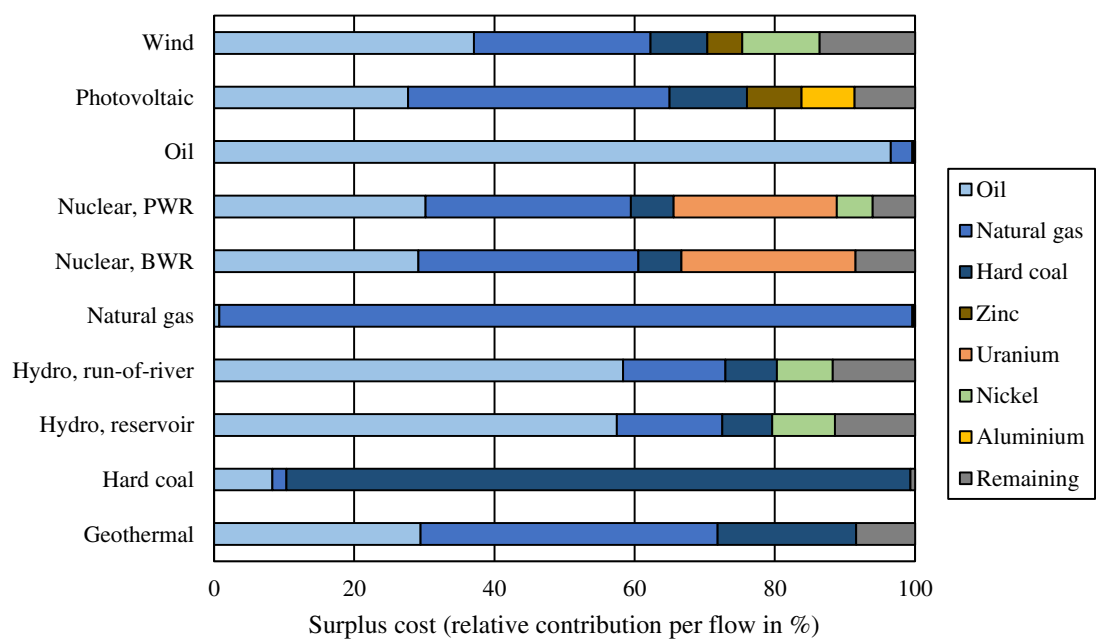

difference between the minimum and maximum value. The high variability in SCPs observed for wind may be explained by regional differences in wind intensity. For wind-powered electricity, Russia, Ukraine and South Africa have the largest surplus costs per megawatt hour of electricity produced, whereas Indonesia, Mexico and Turkey obtain the lowest surplus costs.

In Fig. 4, the average relative contribution to the surplus costs per resource for each electricity source is shown. Mineral resources that contribute with at least $5 \%$ of the total SCP score per technology are individually shown and the rest is grouped in the series 'Remaining mineral resources'. The contribution for all three fossil resources is always displayed. We found that the surplus costs of fossil resource use are always higher compared to mineral resources. For the fossilbased electricity generation technologies, the relative contribution to the total surplus costs by fossil resources is always larger than $99 \%$. For the renewable electricity production technologies, mineral resources contribute 8 to $29 \%$ to the overall surplus costs. Nuclear electricity production technologies show the largest contribution from mineral resource use (33-34\%), mostly resulting from uranium. The mineral resources contributing with at least $5 \%$ of the total SCP are aluminium, nickel and zinc.

\section{Discussion}

\subsection{Comparison with other surplus cost methods}

Existing LCIA methods focused on quantifying the surplus costs resulting from production of abiotic resources include EPS (Steen 1999), ReCiPe (Goedkoop and De Schryver 2009), Ponsioen et al. (2014) and the economic resource scarcity potential (ESP) (Schneider et al. 2014). Although ESP includes the economic dimension, this method encompasses various elements aimed at identifying altogether supply risks associated with resources, aligning thus with criticality approaches. Because the ESPs per resource were not explicitly provided in Schneider et al. 2014, the quantitative comparison with the approach here proposed was not possible to carry out. In EPS and ReCiPe, characterization factors (CFs) expressed as surplus costs were derived for mineral and fossil resources, whereas Ponsioen et al. (2014) derived SCPs specifically for fossil resources. The SCPs for EPS and ReCiPe were retrieved from Steen (1999), Goedkoop and De Schryver (2009) and Roerbech et al. (2014) to be compared with the SCPs here derived combined with those derived by Vieira et al. (2016) (see Fig. 5). The SCPs used for EPS and ReCiPe are available at the Electronic Supplementary Material.
Fig. 5 Surplus cost potential (each it its original unit) from EPS (Steen 1999), ReCiPe (Goedkoop and De Schryver 2009) and those here derived combined with Vieira et al. (2016) for reserves, the latter in the $x$-axis. Both axes are displayed in logarithmic scale

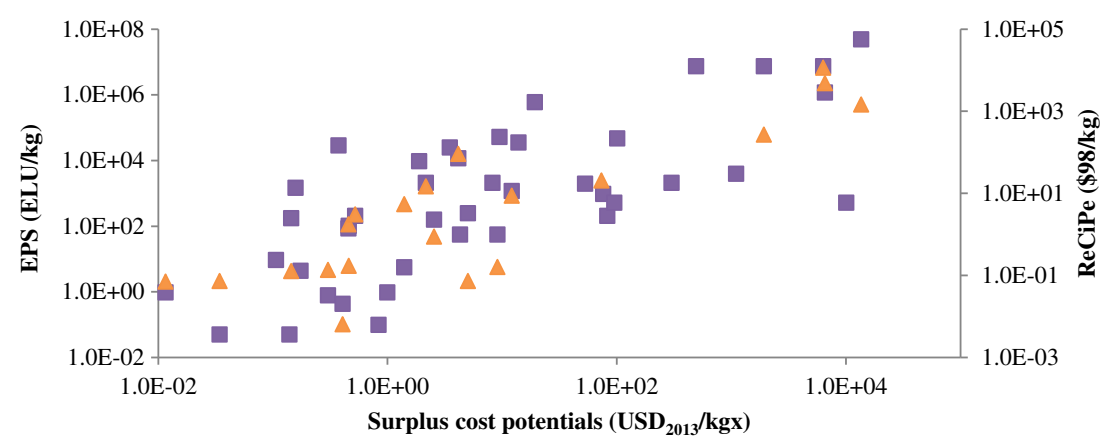

EPS $\triangle \mathrm{ReCiPe}$ 
In the EPS method (Steen 1999), future extraction costs in combined characterisation and weighting factors (ELU) per kilogram were calculated using future sustainable production technology costs. EPS covers a total of 69 resources, 65 mineral and 4 fossil (Roerbech et al. 2014; Steen 1999), for which 41 also have SCPs. The SCPs here derived are in general lower (4 to 7 out of 41) than the CFs derived in EPS. For a specific resource, the SCPs here derived can be up to 2 orders of magnitude larger (for cesium) and 5 orders of magnitude lower (e.g. cadmium).

The characterization factors for resources expressed as surplus costs, expressed in US dollars from base year 1998, in ReCiPe were compared to both sets of SCPs derived in this paper. ReCiPe covers 20 mineral and 5 fossil resources. There were 20 resources covered by both methods. When comparing the values from ReCiPe and the SCPs here derived, there is a maximum of 2 orders of magnitude difference. Although both ReCiPe and the surplus cost method here proposed both assess the extra costs to be paid for extracting future resources, there are key differences between both methods. Our SCP calculations apply mine-specific data for determining relationships between the extraction of resources and the increase in production costs, whereas ReCiPe adopted one constant value. Another important difference is the discounting of future costs applied in the ReCiPe method. In the method applied here, it was chosen not to apply discounting because, according to Hellweg et al. (2003), discounting across generations because of pure time preference should not be applied in LCA.

Ponsioen et al. (2014) derived three sets of characterization factors expressed as surplus costs for fossil fuels only using a method which combines a marginal modelling approach, future production scenarios and discounting. The surplus cost values derived in Ponsioen et al. (2014) with zero discounting (egalitarian perspective) for crude oil, hard coal and natural gas were, respectively, $15.4,7.4$ and $3.4 \mathrm{USD}_{2013}$ per gigajoule (converted with Bureau of Labor Statistics (2014) from US dollars from base year 1998 to 2013). These SCP values are in the same order of magnitude as those obtained in this paper. The difference in the SCPs obtained can be explained by the difference in modelling approach (average vs marginal) and by the use of more recent data in this paper compared to Ponsioen et al. (2014).

\subsection{Limitations}

Our analysis is not without uncertainties which are further discussed below. First, we assumed that cost increases are expected from future extractions following the cumulative cost curves derived from current practice. Although there are several effects of resource extraction leading to cost increase, such as the need to use lower ore grade, more remote and more difficult to process deposits, new technology and innovations and new discoveries can lead to cost decreases (Humphreys 2013; Svedberg and Tilton 2006; Tilton and Lagos 2007; Yaksic and Tilton 2009). For fossil resources, future technology development is accounted for in the estimates made by the International Energy Agency (2013). For mineral resources, technological innovation, economies of scale and new discoveries may partly offset higher costs of extracting resources (Crowson 2012; Curry et al. 2014). Reserves beyond 20-30 years of consumption are rarely identified (Yaksic and Tilton 2009), meaning that new mining projects with lower costs than other running mines in the future may occur. For instance, over the past 30 years, copper resources have more than doubled (Tilton and Lagos 2007). However, over more than a century, copper extraction costs show neither great rise nor fall (Svedberg and Tilton 2006). Despite these observations, potential cost reductions due to new technology development were not included in the SCP calculations of minerals because this is unpredictable (Tilton and Lagos 2007; Yaksic and Tilton 2009). Neglecting these potential future cost reductions in the mineral SCP calculations implies an even lower contribution of mineral resources to the electricity resource footprint.

For the calculation of SCPs for fossil resources, future cost and production estimates from the International Energy Agency (2013) were used. Of course, these are forecasts determined on basis of the depletion of current basin sites and the development and use of new technologies for each specific fossil fuel, both of which are uncertain (International Energy Agency 2013).

The choice to integrate until MFE supposes that all the resource is consumed in the end, although there will be exponentially rising costs. This may not be realistic for resources that can be substituted by more abundant alternative resources. For mineral resources, this assumption can be tested by considering two types of reserve estimates: (1) reserves, which include only identified reserves that are presently economically viable and are likely to be consumed in the shortterm future, and (2) ultimate recoverable resource (URR), which is by definition the ultimate quantity of economically viable reserves over all of human time. As an attempt to estimate URR, also called ultimately extractable reserves (UER) and extractable global resource (EGR), as explored by UNEP (2011a), a rough estimate of URR defined as $0.01 \%$ of the total amount in the crust to $3 \mathrm{~km}$ depth will be used. However, it should be noted that this estimate is highly uncertain because of unknown future circumstances that will continue to influence and modify economic viability and so the final URR estimate. SCPs derived with URR as reserve estimate are on average a factor 3 higher with a maximum of a factor of 5.7 larger than those derived with reserves (see Electronic Supplementary Material). Using the SCPs based on URR, we found a larger contribution of mineral resources compared to SCPs derived with reserves. For the renewable electricity production technologies, mineral resources contribute 8-29\% (reserves scenario) and $17-46 \%$ (ultimate recoverable 
resource scenario) to the overall surplus costs. For nuclear technologies, the difference is up to $20 \%$ more contribution for URR from mineral resources. For fossil resources, only one reserve estimate was used, based on International Energy Agency (2013) estimates. Depending on climate policies and the future development of renewable energy resources, it is unclear whether all the fossil reserves will be actually consumed by society.

In Vieira et al. (2016), SCP values were derived for 12 metals and for the group platinum-group metals using minespecific tonnage and production costs. To allow the applicability of the SCP method within LCA practice, SCP values were derived for over 60 metals, minerals and mineral resource groups extrapolating from price data from 2013. Prices were used because a good correlation was found between the 13 SCP values explicitly derived in Vieira et al. (2016) and their prices. However, we would like to emphasize that this does not imply that there is a causative relationship between current price and SCP. Also, despite the high correlation found, some of the metals deviate from the regression line. For instance, the SCP derived empirically for zinc for reserves is $9.0 \mathrm{USD}_{2013} / \mathrm{kg}$ whereas the value determined with the price correlation is a factor of 22 smaller $\left(0.4 \mathrm{USD}_{2013} / \mathrm{kg}\right)$. This implies that metals which are co-mined predominantly in zinc deposits, as is the case for indium, may also be underestimated when their SCP values are derived on basis of the price correlation. For photovoltaic electricity production, the technology is often associated with indium (Öhrlund (2011). Indium has the largest contribution to the total surplus cost per megawatt hour for photovoltaic but still smaller than $1 \%$. If the SCP for indium is directly derived from the zinc $\mathrm{SCP}$ via $\left(\mathrm{PRICE}_{\text {indium }} / \mathrm{PRICE}_{\text {zinc }}\right) \times \mathrm{SCP}_{\text {zinc }}$, the $\mathrm{SCP}$ of indium reserves increases from $1.0 \times 10^{2}$ to $2.6 \times 10^{3} \mathrm{USD}_{2013} / \mathrm{kg}$. Although this is a significant increase in SCP, the contribution of indium to the total surplus costs of the PV example above becomes $2 \%$ with fossil resources remaining the dominant factor.

Also, there are various limitations with using prices. Prices fluctuate due to factors other than mining and milling costs, which are the ones considered in the SCP approach. For instance, if demand rises much faster than the production capacity of mines, prices increase even with constant production costs because of lack of equilibrium between supply and demand. The price data used for extrapolation is average data for global trade of that metal or mineral. This means that price of both primary as well as secondary material, when applicable, is considered. This is particularly relevant for metals where supply from recycling and the difference between the prices of primary and secondary sources are large (Reck and Graedel 2012). For instance, 'base metals' such as iron, copper and zinc have end-of-life recycling rates of above $50 \%$ (UNEP 2011b) implying that the price of these scrap metals in also lower than from primary sources. Finally, using the average prices of 2013 instead of long-run trend prices as a predictor for mineral SCPs is also a point for discussion. Prices reflect market and geopolitical conditions and policy, thus other than resource scarcity, at a certain moment in time. There can be significant differences between real prices and long-run trend prices (Cuddington and Nülle 2014; Rossen 2015; Tilton and Lagos 2007). Yaksic and Tilton (2009) argue that long-run trend prices offer the most useful insights regarding mineral depletion, and Tilton and Lagos (2007) state that the long-run future equilibrium price can be assumed to converge toward production cost all other things being equal. For this reason, the correlation between SCPs and long-run trend prices was analysed as well (see Electronic Supplementary Material). According to Rossen (2015), the long-run price trend lasts longer than 70 years so average prices for a period larger than 70 years were used, whenever available. The log-linear relationship between surplus cost potential and the long-run trend price of a metal or mineral resource has an explained variance of $92 \%$ and an intercept of -0.50 . This means that the SCP is typically a factor of $3\left(10^{0.50}\right)$ smaller than the price of a metal or mineral resource, whereas when using the real price of 2013, it was a factor of 5. Also, comparing prices from 2013 and long-term (historical) prices, we found a linear relationship with a high explained variance $\left(R^{2}=0.93\right)$ (see Fig. S2 in the Electronic Supplementary Material).

The datasets used for the electricity production technologies are from ecoinvent v3.2. In life cycle inventory libraries, data for capital goods is only roughly modelled and thus incomplete and of relatively poor quality so the surplus costs here calculated may be underestimated (Arvesen and Hertwich 2012). Also, in the calculation of the surplus costs, SCP values for lignite and peat were set at zero because there was no data to derive specific SCP values for these fossil fuels. If we adopt the SCP value of hard coal for lignite and peat as a first proxy, the surplus costs of all electricity technologies considered change less than $8 \%$ (see Electronic Supplementary Material for details).

\section{Conclusions}

The Surplus Cost Potentials calculated for fossil and mineral resources in our study can be considered as a useful step toward a coherent comparison of resource scarcity caused by renewable and non-renewable electricity production technologies. Of course, SCP is an extra life cycle impact assessment indicator next to others that cover other environmental effects, when comparing different electricity production technologies. Fossil and mineral resources have been assessed in the same way, both based on cost-cumulative production relationships as basis to derive SCP values. There are, however, two main differences between them: (1) the SCPs for fossil resources have been derived using past as well as future costs whereas 
the mineral SCPs have been derived by using current cost data of individual mines only, and (2) for minerals, two reserve estimates were used whereas for fossils only one estimate for future production was used. Fossil fuels always dominate surplus costs of electricity production compared to mineral resources, even for renewable technologies that do not require burning of fossil fuels to produce electricity. The electricity production technologies fuelled by fossil resources result in the largest surplus costs and hydropower from reservoir and run-of-river have the lowest surplus costs per megawatt hour produced. This case study shows that the surplus cost method facilitates the evaluation of trade-offs between mineral and fossil resource use in life cycle assessment.

Acknowledgements This research was funded by the European Commission under the 7th framework program on environment; ENV.2009.3.3.2.1: LC-IMPACT-Improved Life Cycle Impact Assessment methods (LCIA) for better sustainability assessment of technologies, grant agreement number 243827. M. Vieira was further supported by the Dutch National Institute for Public Health and the Environment RIVM-project S/607020, Measurably Sustainable within the spearhead Healthy and Sustainable Living Environment, commissioned by the Director-General of RIVM and run under the auspices of RIVM's Science Advisory Board. We thank the ecoinvent centre for support in correcting the datasets for Ferro alloys as well as two anonymous reviewers for their comments and helpful suggestions.

\section{Compliance with ethical standards}

Conflict of interest The authors declare no conflict of interest.

Open Access This article is distributed under the terms of the Creative Commons Attribution 4.0 International License (http:// creativecommons.org/licenses/by/4.0/), which permits unrestricted use, distribution, and reproduction in any medium, provided you give appropriate credit to the original author(s) and the source, provide a link to the Creative Commons license, and indicate if changes were made.

\section{References}

Alam MM, Murad MW, Noman AHM, Ozturk I (2016) Relationships among carbon emissions, economic growth, energy consumption and population growth: Testing Environmental Kuznets Curve hypothesis for Brazil, China, India and Indonesia. Ecol Indic 70:466479

Arvesen A, Hertwich EG (2012) Assessing the life cycle environmental impacts of wind power: a review of present knowledge and research needs. Renew Sust Energ Rev 16:5994-6006

Bureau of Labor Statistics (2014) United States Department of Labor. CPI Inflation Calculator. www.bls.gov/data/inflation_calculator.htm. Accessed 9 July 2014

Crowson PCF (2011) Mineral reserves and future minerals availability. Miner Econ 24:1-6

Crowson P (2012) Some observations on copper yields and ore grades. Resour Policy 37:59-72

Cuddington JT, Nülle G (2014) Variable long-term trends in mineral prices: the ongoing tug-of-war between exploration, depletion, and technological change. J Int Money Finance 42:224-252
Curry JA, Ismay MJL, Jameson GJ (2014) Mine operating costs and the potential impacts of energy and grinding. Miner Eng 56:70-80

Dewulf J, Benini L, Mancini L, Sala S, Blengini GA, Ardente F, Recchioni M, Maes J, Pant R, Pennington D (2015) Rethinking the area of protection "natural resources" in life cycle assessment. Environ Sci Technol 49:5310-5317

Dixon C (2009) What's the relationship between cost and price? http:// cdixon.org/2009/10/17/whats-the-relationship-between-cost-andprice/. Accessed 1 July 2016

Drielsma JA, Russel-Vaccari AJ, Drnek T, Brady T, Weihed P, Mistry M, Perez Simbor L (2016) Mineral resources in life cycle impact assessment - defining the path forward. Int J Life Cycle Assess 21: $85-105$

Ecoinvent centre (2015) ecoinvent v3.2. www.ecoinvent.org. Accessed 6 May 2016

Euratom Supply Agency (2015) ESA average uranium prices. http://ec. europa.eu/euratom/observatory_price.html. Accessed 3 June 2015

European Commission-Joint Research Centre - Institute for Environment and Sustainability (EC-JRC - IES) (2011) Recommendations for life cycle impact assessment in the European context—based on existing environmental impact assessment models and factors. European Union. http://eplca.jrc.ec.europa.eu/uploads/ILCDRecommendation-of-methods-for-LCIA-def.pdf. Accessed 4 November 2013

Goedkoop M, De Schryver A (2009) Mineral resource depletion. In: Goedkoop M, Heijungs R, Huijbregts, MAJ, De Schryver A, Struijs J, Van Zelm R (ed) ReCiPe 2008: a life cycle impact assessment method which comprises harmonised category indicators at the midpoint and the endpoint level. Report I: characterisation factors, first edition. Ministerie van Volkhuisvesting, Ruimtelijke Ordening en Milieubeheer, Den Haag, pp 108-117

Haseeb M, Hassan S, Azam M (2016) (Advanced online publication) Rural-urban transformation, energy consumption, economic growth, and $\mathrm{CO} 2$ emissions using STRIPAT model for BRICS countries. Environ Prog Sustain Energy

Hellweg S, Hofstetter TB, Hungerbühler K (2003) Discounting and the environment: should current impacts be weighted differently than impacts harming future generations? Int J Life Cycle Assess 8:8-18

Hertwich EG, Gibon T, Bouman EA, Arvesen A, Suh S, Heath GA, Bergesen JD, Ramirez A, Vega MI, Shi L (2014) Integrated lifecycle assessment of electricity-supply scenarios confirms global environmental benefit of low-carbon technologies. Proc Natl Acad Sci U S A 112:6277-6282

Humphreys D (2013) Long-run availability of mineral commodities. Miner Econ 26:1-11

International Energy Agency (2013) Resources to reserves 2010. Oil, gas and coal technologies for the energy markets of the future

International Energy Agency (2015) World energy outlook 2015. International Energy Agency, Paris. http://www.iea.org/ publications/freepublications/publication/WEB WorldEnergyOutlook2015ExecutiveSummaryEnglishFinal.pdf. Accessed 22 January 2016

IPCC (2014) Climate change 2014: synthesis report. Contribution of Working Groups I, II and III to the Fifth Assessment Report of the Intergovernmental Panel on Climate Change [Core Writing Team, R.K. Pachauri and L.A. Meyer (eds.)]. IPCC, Geneva, Switzerland, $151 \mathrm{pp}$. http://www.ipcc.ch/pdf/assessment-report/ar5/syr/SYR AR5_FINAL_full_wcover.pdf. Accessed 22 January 2016

Jungbluth N, Frischknecht R (2010) Cumulative energy demand. In: Hischier R, Weidema B (eds) Implementation of life cycle impact assessment methods. St Gallen, Ecoinvent centre, pp 33-40

Kelly TD, Matos GR (2013) Historical statistics for mineral and material commodities in the United States (2013 version): U.S. Geological Survey Data Series 140. http://minerals.usgs.gov/minerals/pubs/ historical-statistics/. Accessed 3 June 2015 
Kitco Metals Inc. (2015) Historical charts and data-London fix. http:// www.kitco.com/charts/. Accessed 3 June 2015

Kleijn R, van der Voet E, Kramer GJ, van Oers L, van der Giesen C (2011) Metal requirements of low-carbon power generation. Energy 36:5640-5648

Klinglmair M, Sala S, Brandão M (2014) Assessing resource depletion in LCA: a review of methods and methodological issues. Int J Life Cycle Assess 19:580-592

Lieberei J, Gheewala SH (2017) Resource depletion assessment of renewable electricity generation technologies - comparison of life cycle impact assessment methods with focus on mineral resources. Int J Life Cycle Assess 22:185-198

Öhrlund I (2011) Future metal demand from photovoltaic cells and wind turbines - investigating the potential risk of disabling a shift to renewable energy systems. Science and Technology Options Assessment (STOA), European Parliament

Pehlken A, Albach S, Vogt T (2017) Is there a resource constraint related to lithium ion batteries in cars? Int J Life Cycle Assess 22:40-53

Ponsioen TC, Vieira MDM, Goedkoop MJ (2014) Surplus cost as a life cycle impact indicator for fossil resource scarcity. Int J Life Cycle Assess 19:872-881

Prado-Lopez V, Wender BA, Seager TP, Laurin L, Chester M, Arslan E (2016) Tradeoff evaluation improves comparative life cycle assessment: a photovoltaic case study. J Ind Ecol 20:710-718

PRé Consultants bv (2015) SimaPro 8.1. www.simapro.com. Accessed 24 February 2016

R Development Core Team (2015) R: a language and environment for statistical computing, version 3.2.1 (2015-06-18). The R Foundation for Statistical Computing, Vienna. www.R-project.org. Accessed 15 July 2015.

Reck BK, Graedel TE (2012) Challenges in metal recycling. Science 337: 690-697

Roerbech JT, Vadenbo C, Hellweg S, Astrup TF (2014) Impact assessment of abiotic resources in LCA: quantitative comparison of selected characterization models. Environ Sci Technol 48:11072-11081

Rossen A (2015) What are metal prices like? Co-movement, price cycles and long-run trends. Resour Policy 45:255-276

Schneider L, Berger M, Schüler-Hainsch E, Knöfel S, Ruhland K, Mosig J, Bach V, Finkbeiner M (2014) The economic resource scarcity potential (ESP) for evaluating resource use based on life cycle assessment. Int J Life Cycle Assess 19:601-610
Sonderegger T, Dewulf J, Drielsma J, Fantke P, Maia de Souza D, Pfister S, Stössel F, Verones F, Vieira M, Weidema B, Hellweg S (2017) Towards harmonizing natural resources as an area of protection in life cycle impact assessment. Int J Life Cycle Assess. doi:10.1007/ s11367-017-1297-8

Steen B (1999) A systematic approach to environmental priority strategies in product development (EPS). Version 2000 - models and data of the default method. Chalmers University of Technology

Steen B, Palander S (2016) A selection of safeguard subjects and state indicators for sustainability assessments. Int J Life Cycle Assess 21: 861-874

Svedberg P, Tilton JE (2006) The real, real price of nonrenewable resources: copper 1870-2000. World Dev 34:501-519

Tilton JE, Lagos G (2007) Assessing the log-run availability of copper. Resour Policy 32:19-23

U.S. Geological Survey (2016) Mineral commodity summaries 2016. U.S. Geological Survey. http://minerals.usgs.gov/minerals/pubs/ mcs/2016/mcs2016.pdf. Accessed 26 February 2016

UNEP (2011a) Estimating long-run geological stocks of metals. Working paper, April 6, 2011. UNEP International Panel on Sustainable Resource Management, Working Group on Geological Stocks of Metal, Paris

UNEP (2011b) Recycling rates of metals - a status report. A Report of the Working Group on the Global Metal Flows to the International Resource Panel. Graedel TE, Allwood J, Birat J-P, Reck BK, Sibley SF, Sonnemann G, Buchert M, Hagelüken C

Vieira MDM, Ponsioen TC, Goedkoop MJ, Huijbregts MAJ (2016) Surplus cost potential as a life cycle impact indicator for metal extraction. Resources 5. http://www.mdpi.com/2079-9276/5/1/2

World Nuclear Association (2014) Heat values of various fuels. www. world-nuclear.org/info/Facts-and-Figures/Heat-values-of-variousfuels/. Accessed 1 September 2014

Yaksic A, Tilton JE (2009) Using the cumulative availability curve to assess the threat of mineral depletion: the case of lithium. Resour Policy 34:185-194

Zaman K, Abdullah A, Khan A, Nasir MRB, Hamzah TAAT, Hussain S (2016) Dynamic linkages among energy consumption, environment, health and wealth in BRICS countries: green growth key to sustainable development. Renew Sust Energ Rev 56:1263-1271 